\title{
AZ EGÉSZSÉGTUDATOS ÉLELMISZER-FOGYASZTÁS NETNOGRÁFIAI VIZSGÁLATA A DIGITÁLIS KORBAN
}

\author{
$\longrightarrow$ \\ A NETNOGRAPHIC STUDY OF HEALTH-CONSCIOUS FOOD CONSUMPTION \\ IN THE DIGITAL ERA \\ - \\ ${ }^{1}$ FEHÉR, ANDRÁS \\ ${ }^{1}$ FARKAS, NOÉMI DÓRA \\ ${ }^{1}$ BOROS, HENRIETTA MÓNIKA \\ ${ }^{2}$ VÉHA, MIKLÓS \\ ${ }^{1}$ SZAKÁLY, ZOLTÁN \\ to \\ ${ }^{1}$ Debreceni Egyetem, Gazdaságtudományi Kar, Marketing és Kereskedelem Intézet \\ (University of Debrecen, Faculty of Economics and Business, Institute of Marketing and Commerce) \\ H-4032 Debrecen, Böszörményi út 138. \\ ${ }^{2}$ Naturtrade Hungary Kft. \\ H-6725 Szeged, Szabadsajtó utca 54. \\ e-mail: feher.andras@econ.unideb.hu
}

Health-conscious lifestyles and the consumption of foods which are considered healthy are becoming increasingly important globally and domestically. Thanks to digitisation, the consumer has a wide range of new and innovative ways to obtain useful information. Social media and its elements have reformed access to information over the past decade. The main objective of our research was to assess the impact of digitisation on healthy food consumption. In this article, we analysed particular social media platforms (Facebook, Instagram and Youtube) with a netnographic observation and examined the role of influencers in health-conscious food consumption. During secondary research, we clarified basic definitions and analysed recent and near-term trends. In the primary research, the netnographic survey was conducted in two sessions (September and October 2018 and December 2019). The aim was to broaden the research while comparing the results of the two observation sessions. Only Hungarian language sites were used for our observations. We analysed the Facebook pages and groups related to healthy eating. For the terms related to the topic under study (e.g., "healthy lifestyle" and "conscious eating"), we identified the same pages in most cases. So a given page has appeared for more than one search term. The creators of the groups typically include 4-5 keywords in the title at a time. We have analysed the number of hashtags with and without accents associated with health-conscious, free-from and plantbased nutrition. The majority of the analysed hashtags showed a tendency for their accented variants to grow more than non-accented ones in the past year. In addition, we systematized the Hungarian influencers with Youtube channel in the research topic. Based on the results, it can be stated that relatively few influencers operate a channel with a higher number of subscribers in the fields of healthy eating and healthy lifestyle. To sum up, the mention of healthy lifestyle in social media is complex and it is not tightened to health-conscious food consumption.

KuLCSSZAVAK: egészségtudatos élelmiszer-fogyasztás, digitális kor, netnográfiai kutatás, közösségi média marketing
KEYWORDS: health-conscious food consumption, digital era, netnographic research, social media marketing 


\section{BEVEZETÉs - INTRODUCTION}

Az egészséges életmódra történő tudatos áttérés egyre fontosabbá vált a fogyasztók számára nemcsak globális, hanem hazai értelemben is. A megfelelő táplálkozás kialakítása elengedhetetlen feltétele az életmódváltásnak, amelyhez szükséges a fogyasztó alapos előzetes tájékozódása. A digitalizáció számos új és újszerü lehetőséget adott a fogyasztó kezébe, hogy az élelmiszer-vásárlásukat megelőzően tájékozódjanak a termékekről. A tudatosság növekedésével pedig egyenes arányú változás tapasztalható az egészséges élelmiszerek egyre szélesebb körű elterjedésében.
Fontos kiemelni, hogy SZÁNTÓ (2008) szerint az élelmiszerek piaca az egészségügyi piacon belül az egészségmegóvás és betegségmegelőzés piacába tartozik (1. ábra). Így SZÁNTÓ (2008) kutatási modellje alapján kijelenthető, hogy az élelmiszerpiac az egészséget pozitívan befolyásoló piacok egyik legfóbb elemei közé tartozik. Azonban számos aggálylyal és akadályozó tényezővel találkozhatnak azok a fogyasztók, akik hajlandók elindulni az egészségesebb életmód felé vezető úton. Számos esetben felmerül bennük a kérdés, hogy mi tekinthető „egészséges” élelmiszernek? Ezt a dilemmát feltétlenül érdemes releváns kutatások segítségével feloldani.

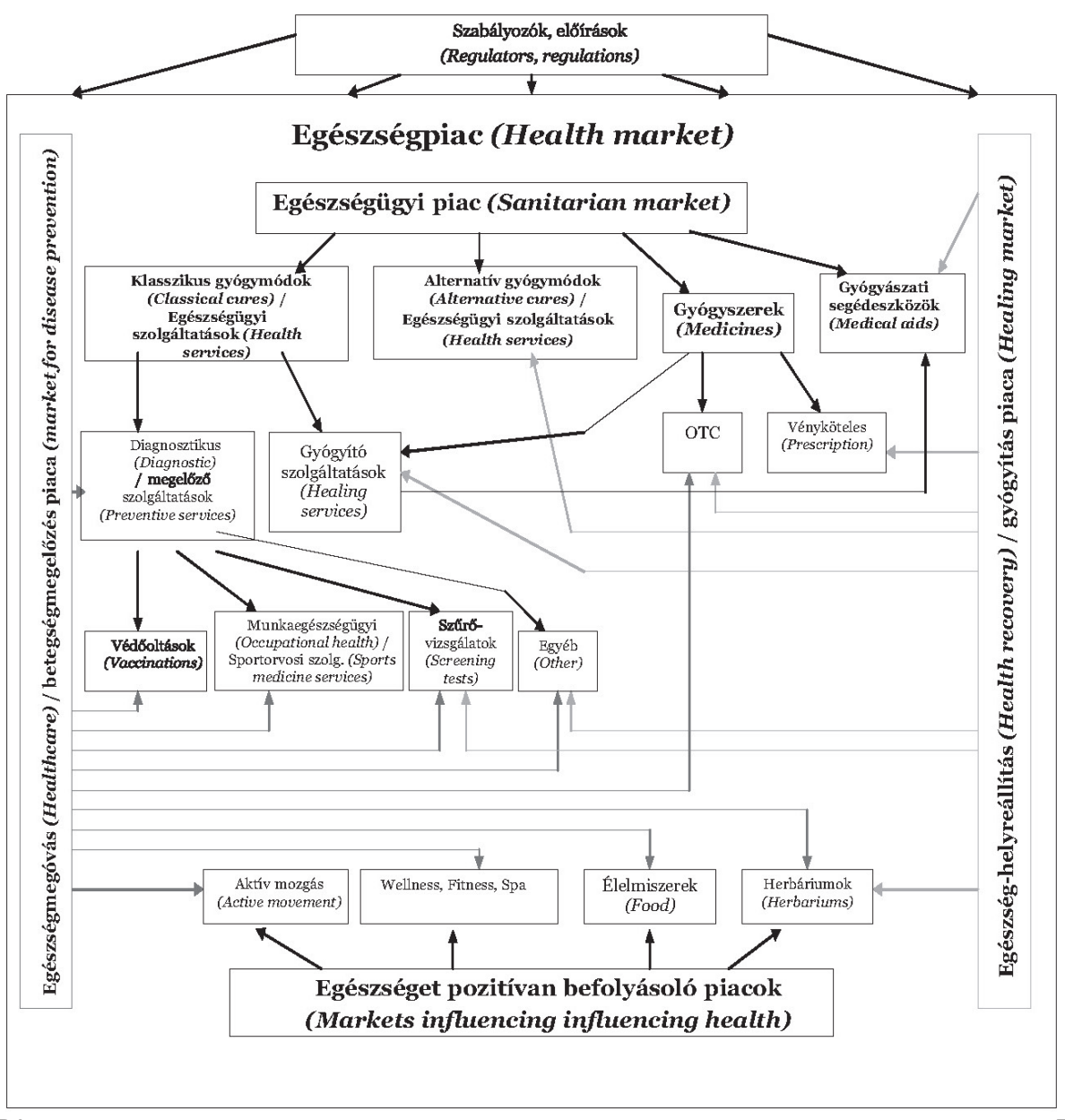

1. ÁBRA

FIG. 1

Az egészségpiac multilaterális modellje (The Multilateral Model of the Health Market)

Forrás (Source): SZÁNTÓ (2008) 
Megkülönböztetjük az élelmiszervásárlások hagyományos (bolti) és internetes/online (webáruház) módszereit. Az élelmiszerek beszerzési módjától függetlenül, a fogyasztók hagyományos információforrások helyett, egyre inkább az internetes forrásokból tájékozódnak a vásárlást megelőzően. Érdekes kutatási területként azonosítható annak az alapos feltérképezése, hogy melyek az élelmiszerekről történő hagyományos és online információkeresés legfőbb különbségei. Egy korábbi kutatás során FEHÉR (2016) igazolta, hogy hazánkban megjelent a digitális élelmiszer-fogyasztók azon csoportja, amelynek tagjai az élelmiszerekről többnyire az interneten tájékozódnak, illetve alkalmanként az élelmiszereket már online vásárolják meg. TARI (2018) az online élelmiszervásárlási szokásokkal kapcsolatban végzett kutatásokat magyar és amerikai online vásárlók bevonásával. Azonban a korábbi vizsgálatokat specializálva fontos lenne megállapítani, hogy a hagyományos és az online vásárlás milyen hatással van az egészségesnek minősülő élelmiszerek beszerzésére.

$\mathrm{Az}$ internetes információforrások közül napjainkban az influenszerek (véleményvezérek) különösen fontos szerepet töltenek be. SZILÁGYI (2018:48) szerint az influenszerek véleményükkel és viselkedésükkel hatással vannak az embertársaikra. Lehetnek celebek, sztárok, bloggerek és vloggerek. Ezek a személyek általában a közösségimédia-platformok hírességei, akik nagyszámú követővel rendelkeznek. Tevékenységeikkel közvetlenül képesek befolyásolni a fogyasztók információkeresését és így hatást gyakorolnak vásárlási döntéseikre is. Hazai körökben az elmúlt két-három évben erőteljesen nőtt a jelentőségük. KÉRI (2018) szerint a hazai vállalkozások 37\%-a dedikál büdzsét kifejezetten influenszermarketing célokra. Az Oberlo által készített 2018. évi nemzetközi statisztikából pedig kiderül, hogy a vevők 49\%-a figyelembe veszi az influencerek véleményét a vásárlás előtt (MOHSIN, 2019).

A kutatásunk során a legfóbb célkitüzésünk, hogy felmérjük a digitalizáció hatásait az egészségtudatos élelmiszer-fogyasztás terén. Ennek során kiemelt hangsúlyt kap az információkeresés és a vásárlás szakaszainak feltérképezése. Jelen cikkben a kutatási területünket leszúkítjük az egészségtudatos élelmiszer-fo- gyasztás közösségi médiában való megjelenésére. Ennek vizsgálatául netnográfiai kutatást hajtottunk végre. A kutatási kérdéseink az alábbiak: Milyen a közösségi média online véleményvezéreinek (influenszerek) szerepe az egészségtudatos élelmiszer-fogyasztással kapcsolatban? Melyek az egészségtudatos élelmiszer-fogyasztás témában azonosítható legfontosabb keresőkifejezések? Milyen a közösség informálása szempontjából általános jellegú (nem az influenszerekhez kötődő) Facebook-oldalak és -csoportok találhatók meg a közösségi médiában?

\section{SZAKIRODALMI ÖSSZEFOGLALÓ}

\section{- THEORETICAL BACKGROUND}

A következő részben definiáljuk az egészséget és az egészségi állapotot, illetve meghatározzuk az egészségmagatartást. Ezt követően kitérünk az egészséges élelmiszerek fogyasztásának trendjeire. Továbbá feltérképezzük a digitalizáció hatását az élelmiszer-fogyasztói magatartásra, illetve elemezzük az influenszermarketinget.

\subsection{Az egészség, egészségi állapot és az egészségmagatartás definiálása és jellemzői - Definition and Characteristics of Health, Health Condition and Health Behaviour}

Az egészség kifejezésére számtalan meghatározás született az elmúlt évtizedek során. A 21. századi értelmezés szerint TRINGER (2002) kifejtette: „Az egészség olyan állapot, amelyet az anatómiai integritás, a teljesítményre való képesség, a személyes értékek, a családi, munka- és közösségi szerep, a fizikai, biológiai és társadalmi stresszel való megküzdés képessége, a jólét érzése, a betegség és a korai halál rizikóitól való mentesség jellemez". A GfK és Tárki 2011. évben megvizsgálta, hogy a magyar lakosság miképp vélekedik az egészségről. A megkérdezettek többsége a betegség nélküli állapottal azonosította az egészséget. Azonban a válaszadók 32\%-a az egészséges életmódot jelölte meg (BERNÁT, 2012).

Hazánk sajnálatos módon élenjár a különféle civilizációs betegségek általi halálozások 
tendenciáiban. Többek között az összes halálozás felét a keringési rendszer betegségei okozzák. Ezek általában szív-érrendszeri, illetve daganatos betegségek. Mindezekhez hozzájárul a túlsúly és az elhízás, illetve a stressz kockázati tényezője (SZAKÁLY, 2011). A hazai lakosok szubjektív egészségképét tekintve elmaradás tapasztalható az EU átlagához képest. A magyarok 16,2\%-a értékeli az egészségét nagyon jó állapotúnak, míg ez az arány az EU tagállamainak lakosainál 21,8\% (EUROSTAT, 2018a).

$\mathrm{Az}$ egészségi állapotot meghatározó legfontosabb tényezőket LALONDE (1974) egy modellben azonosította, amelynek során négy hatótényezőt differenciált: környezet, genetikai-biológiai tényezők, egészségügyi ellátás és az életmód. A korábbi kanadai népjóléti miniszter szerint az életmód (43\%) befolyásolja a legnagyobb mértékben az egészségi állapotot. Az aktuális kutatás során az életmód tényezőn belül a táplálkozás szerepére koncentrálunk, amely a fizikai aktivitás mellett elengedhetetlen szerepet játszik az egészségesebb életmód kialakításában.

Mielőtt feltérképezzük az egészségfogyasztás tendenciáit, nagyon lényeges definiálni az egészségmagatartást, amely HARRIS és GUTEN (1979) szerint minden olyan cselekvést magába foglal, amelyet egy személy azért végez, hogy megalapozza és ezt követően fenntartsa az egészségét, függetlenül attól, hogy az általa észlelt egészségi állapotát objektíven képes-e megítélni. Mindezt BÍRÓ (2008) kiegészítette az egészségmagatartás összetevőivel, szerinte az egészséges táplálkozás, a rendszeres testmozgás, a pihenés és az alvás, a szellemi aktivitás és a rendszeres testmozgás tényezőiből határozható meg.

A GfK Egészséggazdasági Monitor (2012) kutatása szerint a 2011. évben a hazai egészségpiac becsült értéke 3500 milliárd forint volt, amelyből egyharmad részben az egészségügyi rendszer és kétharmad részben a lakossági fogyasztás részesült. Utóbbin belül az egészséges étkezés több mint 300 milliárd forintot tett ki. A kutatásból kiderült többek között, hogy a hazai háztartások az egészséges életmóddal kapcsolatos kiadásaik 52\%-át egészségvédő élelmiszerekre költik. Így ez minősül a legjelentősebb egészségkiadásnak.

\subsection{Az egészséges élelmiszer-fogyasz- tás trendjei - Trends in Healthy Food Consumption}

TÖRŐCSIK (2011) az egészség megatrenden belül az egészségtudatos élelmiszer-fogyasztás számos lehetőségét definiálta (2. ábra). Kiemelte a funkcionális élelmiszereket (functional food), amelyek az élelmiszer egészségvédő hatását fokozó összetevővel vannak ellátva (SZAKÁLY et al., 2019). A „pharma food” kategória esetében már gyógyító élelmiszerekről beszélhetünk, amelyek bizonyos betegségek elleni gyógyszereket juttatnak a szervezetbe. A „health food” és „wellness food” kategóriák is fontos részét képezik az egészség dimenziónak, ezeknél az egyes élelmiszerek észlelt egészséget javító hatása többnyire szubjektív a fogyasztók részéról. A „bio food” egyszerre képezi az egészség-, illetve környezettudatosság értékeit. Az elmúlt évek során egyre jelentősebb szerepe van a „free-from food”-nak vagyis a valamilyen összetevőtől mentes élelmiszereknek (a későbbiek során „mentes” élelmiszerként említjük). Ennek oka, hogy egyre többen rendelkeznek valamely élelmiszer-összetevővel szembeni allergiával vagy érzékenységgel (pl. glutén-, laktóz-érzékenység). Végezetül érdemes kiemelni a különféle növényi alapú étkezési módokat (pl. vegán, keto), amelyek egyre inkább kezdenek beépülni az egészséges táplálkozás paradigmájába. 


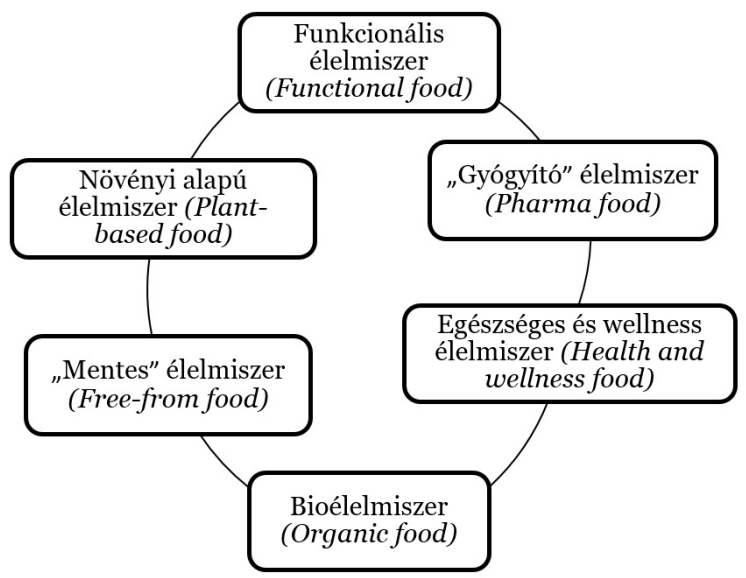

2. ÁBRA

Egészségtudatos élelmiszer-fogyasztás kategóriái

FIG. 2 (Categories in Healthy Food Consumption)

Forrás (Source): Saját szerkesztés TÖRÖCSIK (2011) alapján (Authors'own compilation based of TÖRÓCSIK (2O11)

\subsection{A digitalizáció hatása az élelmi- szer-fogyasztói magatartásra - Impact of Digitisation on Food Consumer Behaviour}

A cikk előző részeinél már utaltunk a digitalizáció jelentős hatására korunk élelmiszer-fogyasztói magatartására vonatkoztatva. Mi sem bizonyítja jobban az előző összefüggést, mint hogy globális szinten a lakosok 58,8\%-a aktív internetezőnek tekinthető, míg hazánkban a vizsgált mutató az EU szintjéhez közel hasonlóan 90\%-os (IWS, 2019). Tehát rengetegen interneteznek a mindennapok során és leggyakoribb tevékenységként internetes kereséssel töltik el a böngészésük jelentős részét. Ezért feltételezhetjük, hogy az élelmiszer-vásárlásaikat megelőzően vagy az egészségtudatos táplálkozással kapcsolatban is fontos platformokat látogatnak meg az interneten, hogy megalapozzák későbbi döntésüket. Az EUROSTAT (2018b) adatai alapján a hazai aktív internetezők 56\%-a keres online felületen egészséggel kapcsolatos információkat. MOSKOWITZ és szerzőtársai (2004) a funkcionális élelmiszerekhez kötődő online információkeresést figyelték meg. Szerintük az egyes internetes felületek kiváló lehetőséget biztosítanak, hogy a látogatók informálódjanak ezekről a speciális élelmiszerekről. FORGÁCS és szerzőtársai
(2013) kutatásuk során felismerték, hogy a mobiltelefon jelentősége egyre inkább felértékelődött a szakértői (pl. orvosok, dietetikusok) információközlés esetében.

\subsection{Az influenszermarketing jellemzői hazánkban - The Characteristics of Influencer Marketing in Hungary}

Az influenszereket alkalmazó marketingstratégia lényege, hogy a vállalkozások szerződést kötnek valamilyen közösségimédia-platformon megtalálható influenszerrel, aki egy konkrét juttatás fejében (pl. pénzbeli fizetés, termékminta) a terméket vagy a szolgáltatást reklámozza és ideiglenesen a márka szószólójává válik (SZÉKELY et al., 2009).

$\mathrm{Az}$ influenszermarketing elsődleges platformjai az Instagram, a Facebook és a YouTube. Ilyen típusú marketinggel a leghatékonyabban a vásárlóképes 18-32 éves korosztály tagjai érhetők el, akik a hagyományos hirdetési megoldásokra kevésbé kíváncsiak és legalább napi 2-4 órát eltöltenek a közösségimédia-platformokon (KÉRI, 2018).

PETRUSKA (2017) szerint a Z generációra (1995 és 2009 között születettek) jellemző leginkább, hogy elsődleges információforrásnak tekintik az influenszereket. Nem feltétlen az számít nekik, hogy celebeket (hírességeket) 
kövessenek a közösségimédia-oldalakon. A legfontosabb számukra, hogy olyan influenszert tudjanak követni, aki a sajátjukhoz nagyon hasonló élettel rendelkezik.

A szakirodalom számos módon kategorizálja az influenszereket. JÁNOSKA (2018) kategorizálása szerint az alábbi típusok különböztethetők meg: a mikroinfluenszerek csupán pár ezres követőtáborral rendelkeznek, így különösen hitelesek és célzottan képesek eljuttatni az üzeneteiket a célcsoportnak. A vállalkozások még csak kezdetleges partnerkapcsolatot alakítanak ki velük. A makroinfluenszerek igazi „bennszülöttek”, akik az aktív online tevékenységüknek hála váltak elismert influenszerré. Sokan több százezres és milliós követőtáborral rendelkeznek. Üzleti szempontból közvetlenül kevésbé elérhetők, leggyakrabban menedzserek, ügynökségek útján lehet leszerződni velük. A megainfluenszerek a celebnek számító személyek, akik sokszor a hagyományos médiában váltak híressé, majd ezzel a népszerüségükkel tudták az influenszer tevékenységüket hatékonyan megalapozni. Nagyon megválogatják, hogy milyen partnerekkel lépnek kapcsolatba.

Az influenszerek kiválasztására a hazai vállalkozásoknak számos lehetősége kínálkozik, azonban az egyik legjobb platform erre a célra a www.influencerkereso.hu, ahol az egyes véleményvezérek rangsorolásánál három lényeges tényező szerint differenciálnak. Az influenszereknél fontos, hogy hány felhasználót tudnak elérni (reach), mennyire képesek a termékeket/szolgáltatásokat beépíteni a legyártott tartalomba (rezonancia) és mennyire hitelesen képesek a kommunikációt végrehajtani (relevancia) (JÁNOSKA, 2018). Az influenszerek hatékonysága az általuk gyártott tartalom hitelességével egyenesen arányos (MAJLÁTH, 2018). A vállalkozások számára a cél megtalálni azt a véleményvezért, akihez a termék vagy szolgáltatás legközelebb áll (HALMOS et al., 2018). Az egészségtudatos életmóddal kapcsolatba hozható influenszerek esetében fontos szerepet játszanak a fitnesziparban tevékenykedők (pl. Béres Alexandra, Rubint Réka), a sportban híressé válók (pl. Hosszú Katinka), a gasztronómiában tapasztalatokat szerzők (pl. Csorba Anita) és a dietétikai, illetve táplálkozástudományi körökben (pl. Antal Emese) ismertté váló véleményvezérek.
$\mathrm{Az}$ influenszermarketingben kiemelten fontos szerepet játszanak az úgynevezett hashtagek. Napjainkban a kettőskereszt (\#), azaz a hashtag szinte mindenhol megtalálható a hagyományos és közösségi médiumokban. A hashtag támogatja a felhasználókat abban, hogy megtalálják a többi felhasználó általi említéseket egy adott témakörben. Tehát az adott kulcsszó vagy kifejezés elé beillesztett kettőskereszt segítségével kereshetővé válnak ezek a szavak (MÁTÉ, 2014). A We Are Social Media 35 tényezőt gyưjtött össze, amelyek alátámasztják az Instagram kiemelt szerepét a közösségi médiában. Az eredményeik alapján többek között kijelenthető, hogy a legalább egy hashtaggel ellátott bejegyzések átlagosan 12,6\%-kal nagyobb felhasználói bevonódást eredményeznek, mint a hashtag nélkül közzétettek. Továbbá az Instagramon megosztott szövegek 50\%-a valamilyen hangulatjelet vagy hashtaget tartalmaz (SOCIAL DAILY, 2017).

\section{ANYAg ÉS MÓDSZER - MATERIAL} AND METHOD

A vizsgálataink vázát a legfrissebb szakirodalmi áttekintésekre építettük fel. Hangsúlyosan kezeltük a kutatással kapcsolatos alapvető definíciók értelmezését. Továbbá a legfrissebb és a közeljövőre vonatkozó trendeket vettük górcső alá, amelyek megfelelő támpontot adnak a digitalizáció élelmiszer-fogyasztói magatartásra gyakorolt hatásairól.

A szekunder kutatás mellett primer információgyüjtést is végeztünk, amelynek során egy kvalitatív kutatási eljárást, a netnográfiai elemzést alkalmaztuk. Az ilyen típusú kutatások során a kutatók online kommunikációs csatornákon (blogok, közösségi oldalak, weboldalak és fórumok) elemzik a felhasználók preferenciáit (DÖRNYEI, 2008; DÖRNYEI és MITEV, 2010; FARKAS, 2019). A strukturált tartalomelemzés alkalmazásával jelen kutatásban különféle közösségimédia-platformokon (Facebook, Instagram és YouTube) figyeltük meg, hogy az egészségtudatos élelmiszer-fogyasztás milyen módon jelenik meg. A kutatás korlátja, hogy csupán a vizsgált online terekben kommunikálók megnyilvánulásait tudjuk mérni, így általános következtetéseket levonni a tel- 
jes lakosságra vonatkoztatva nem lehet. Azonban a kutatás eredményei megfelelő alapként szolgálhatnak további kvalitatív (pl. fókuszcsoportos kutatás) vagy kvantitatív (pl. kérdőíves felmérés) kutatások lebonyolításához.

A kutatás során minden tekintetben igyekeztünk betartani a netnográfiai kutatás lebonyolításának egyes lépéseire vonatkozó előírásokat (GÁL et al., 2017):

- Kulturális entrée: A kutatás megkezdésekor megfogalmaztunk egy kutatási kérdést: Milyen a közösségi média online véleményvezéreinek (influenszerek) szerepe az egészségtudatos élelmiszer-fogyasztással kapcsolatban? A kutatási kérdés jellegéből adódóan az online források körét a közösségi oldalakra szúkítettük le, amelyek közül a Facebook, Instagram és YouTube került kiválasztásra ${ }^{1}$. A kutatói részvétel szintjének meghatározása során a megfigyelő szerepet választottuk, tehát nem kapcsolódtunk bele a beszélgetésekbe. Az influenszermarketing hatásainak vizsgálatára szakértői (pl. dietetikusok, táplálkozási tanácsadók) és nem szakértôi insightok (pl. magukat egészségtudatosnak vélő fogyasztók) különböztethetők meg. A kutatásunk során főleg a nem szakértői insight-okat elemeztük.

- Adatgyüjtés, adatelemzés: A források azonosítása után kiválasztottuk a releváns tartalmakat és feldolgoztuk azokat. A Facebookon az egészséges táplálkozással kapcsolatos oldalakat és csoportokat (nyílt és zárt) elemeztük. A YouTube-on az „egészséges" élelmiszer és táplálkozás témában differenciáltuk az influenszereket. Az Instagramon az egészségtudatos élelmiszer-fogyasztás általánosságaival, a „mentes” és a növényi alapú élelmiszer-fogyasztással kapcsolatos hashtagek (\#) említéseit vettük górcső alá.

- Hiteles interpretáció: A kutatás során a vizsgált említéseket hűen és jelentősebb torzítás nélkül interpretáltuk.

- Etikus kutatás: A kutatás során a felhasználók szószerinti véleménye nem került elemzésre, így különböző engedélyeket nem tartottunk szükségesnek kikérni. A megfigyelés során a vizsgált témakörben felelhető oldalak és csoportok elnevezéseit említjük, amelyek nem sértenek személyiségi jogokat.

- Visszajelzés a közösség tagjaitól: Az etikus kutatás részben leírtak alapján nem tartottuk szükségesnek a visszajelzést a vizsgált közösségek tagjainak.

A netnográfiai kutatást két szakaszban bonyolítottuk le: 2018. szeptemberében és októberében, illetve 2019. decemberében. A cél a két szakaszban feltárt kutatási eredmények összehasonlítása és az ebből származó következtetések levonása volt. A 2018-ban vizsgált közösségimédia-felületek figyelembe vétele mellett, a 2019. évi kutatás során részletesebb elemzés zajlott, amelynek eredményeképp a korábbiakban nem vizsgált, vagy azóta újonnan létrejövő oldalakat, csoportokat és csatornákat is bevontunk az elemzésbe. Ennek köszönhetően nem mindenhol vált lehetővé az összehasonlítás. Az újonnan megfigyelt platformok kutatásban való szerepeltetését több tényező is indokolja. Egyrészt önmagukban is sokatmondó a részletes elemzésük, másrészt jó alapot szolgálhatnak a következő években történő összehasonlító kutatásokhoz.

\section{Eredmények - RESUlts}

Ebben a részben a netnográfiai kutatás eredményeit elemezzük részletesen. A kutatás eredményeit három aspektusból mutatjuk be. $\mathrm{Az}$ első részben az egészséges táplálkozással kapcsolatos Facebook-oldalakat és -csoportokat vesszük górcső alá. Ezt követően az egészségtudatos, a „mentes” és a növényi alapú élelmiszer-fogyasztással kapcsolatos hashtageket elemezzük az Instagramon. Végül a témában érintett influenszereket térképezzük fel Youtube-csatornáik figyelembe vételével.

1A HOOTSUITE DIGITAL (2018) és az INOW RESEARCH (2018) kutatásai során a hazai aktív internetező populáció (7,7 millió fő; 79\%) közösségimédia-fogyasztási szokásait mérték fel, amelynek során kiderült, hogy a Facebookon az aktív internetezők 83\%-a, az Instagramon a 28\%-uk, a YouTube-on az 56\%-uk található meg. 


\subsection{Egészséges táplálkozással kapcso- latos Facebook-oldalak és -csopor- tok - Facebook Pages and Groups on Healthy Nutrition}

A keresések során az „egészséges táplálkozás”, az „egészséges étkezés”, az „egészséges életmód”, a „tudatos táplálkozás” és a „tudatos életvitel” kifejezések kerültek elemzésre. A keresett oldalaknál és csoportoknál a Facebook különböző kategóriákat (pl. gyógyítás és egészség) határoz meg. Az előzőek során felsorolt keresőkifejezésekre történő rákeresésnél az esetek többségében ugyanazok az oldalak és csoportok jelentek meg. Például az „egészséges táplálkozás"-ra rákeresve egy adott oldal ezt követően megjelent az „egészséges étkezés” keresőkifejezésnél is.

A Facebook-oldalaknál a keresési feltételek alapján kizárólag aktív oldalakat látogattunk meg (az elmúlt egy év során tapasztalt aktivitás). Jelen cikkben a minimum 5000 kedvelővel rendelkező oldalakat elemezzük (1. táblázat), amelyek nem üzletszerűen (nem minősül boltnak, tehát nem termék vagy szolgáltatás értékesítése céljából végzi a Facebook-tevékenységét), hanem a közösség informálása érdekében folytatják a közösségimédia-jelenlétüket. Mindezt a Facebook-oldalukon található névjegyen belüli besorolás alapján ítéltük meg.

1. TÁBLÁZ̈AT

TABLE 1

Az egészséges táplálkozással kapcsolatos Facebook-oldalak vizsgálata azok kedveltsége alapján (Examination of Facebook Pages on Healthy Nutrition Based on the Number of Followers)

\begin{tabular}{|c|c|c|c|c|}
\hline \multirow{2}{*}{$\begin{array}{l}\text { Facebook-oldalak } \\
\text { (Facebook pages) }\end{array}$} & \multirow{2}{*}{$\begin{array}{l}\text { Kategória } \\
\text { (Category) }\end{array}$} & \multicolumn{2}{|c|}{$\begin{array}{l}\text { Oldalkedvelók, fó } \\
\text { (Page followers, } \\
\text { capita) }\end{array}$} & \multirow{2}{*}{ 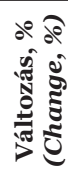 } \\
\hline & & 2018 & 2019 & \\
\hline „EgészségKalauz” & Gyógyítás és egészség (Healing and health) & 84534 & 110420 & 30,6 \\
\hline „AntalVali.co.hu” & $\begin{array}{l}\text { Egészséges életmód és wellness (Healthy } \\
\text { lifestyle and wellness) }\end{array}$ & 84221 & 83492 & $-0,9$ \\
\hline „Ez Zsír” & Közösség (Community) & 53295 & 52592 & $-1,3$ \\
\hline „Tudatos Életmód - töltődj fel” & Közösség (Community) & $\mathrm{nv}$ & 40387 & nv \\
\hline „Táplálkozás, Testedzés Imolával,, & Egészség és szépség (Health and beauty) & 34000 & 34394 & 1,2 \\
\hline „Vitálmenü - Egészséges receptek” & Konyha és fözés (Kitchen and cooking) & 33000 & 32786 & $-0,6$ \\
\hline „Egészség Egyetem” & Közösség (Community) & $\mathrm{nv}$ & 27147 & $\mathrm{nv}$ \\
\hline „Palkó Noémi Életmód Mentor” & Táplálkozási tanácsadó (Nutrition consultant) & nv & 20777 & nv \\
\hline „MÉG IDÉN” & Egészség és szépség (Health and beauty) & 21240 & 20558 & $-3,2$ \\
\hline „MDOSZ - Terítéken az egészség” & $\begin{array}{l}\text { Közösségi szervezet } \\
\text { (Community organization) }\end{array}$ & 14216 & 20124 & 41,6 \\
\hline „Paleolit táplálkozás” & $\begin{array}{l}\text { Egészséges életmód és wellness (Healthy } \\
\text { lifestyle and wellness) }\end{array}$ & 17594 & 17720 & 0,7 \\
\hline $\begin{array}{l}\text { „Perjes Kinga - életmód és táplálkozá- } \\
\text { si tanácsadó” }\end{array}$ & $\begin{array}{l}\text { Egészséges életmód és wellness, táplálkozási } \\
\text { tanácsadó (Healthy lifestyle and wellness, } \\
\text { nutrition consultant) }\end{array}$ & $\mathrm{nv}$ & 17294 & $\mathrm{nv}$ \\
\hline „Egészséges életmód - 21 nap alatt” & Közösség (Community) & $\mathrm{nv}$ & 15517 & $\mathrm{nv}$ \\
\hline „Egészséges receptek gyűjteménye” & Közösség (Community) & 10957 & 12343 & 12,6 \\
\hline $\begin{array}{l}\text { „Vitalzone.hu - Minden, ami alakfor- } \\
\text { málás, és egészséges életmód” }\end{array}$ & Közösség (Community) & $\mathrm{nv}$ & 9244 & $\mathrm{nv}$ \\
\hline $\begin{array}{l}\text { „Mozdulj Anyu - táplálkozás, diéta, } \\
\text { edzés, motiváció” }\end{array}$ & $\begin{array}{l}\text { Egészséges életmód és wellness, táplálkozási } \\
\text { tanácsadó (Healthy lifestyle and wellness, } \\
\text { nutrition consultant) }\end{array}$ & 7474 & 8318 & 11,3 \\
\hline „Testtudatos Táplálkozás” & Egészség és szépség (Health and beauty) & 5787 & 6068 & 4,9 \\
\hline
\end{tabular}

Forrás (Source): Saját szerkesztés (Authors'own compilation) 
Az „EgészségKalauz” és „AntalVali.co.hu” oldalak a kedvelőik számát illetően kiemelkednek a többi vizsgált oldal közül. Az egy évvel korábban is vizsgált oldalak többségénél a kedvelők száma minimálisan csökkent és csak néhány esetben mutatkozik számottevő növekedés. A csökkenés okát jelen vizsgálatukban nem részletezzük. Érdemes kiemelni az „MDOSZ - Terítéken az egészség” oldalát, amely több mint 40\%-os növekedést ért el a kedvelők terén. A vizsgált oldalak kategóriatípusait figyelembe véve nem állapítható meg egyértelmű tendencia, tehát szinte minden megnevezés képviselteti magát.

A Facebook-csoportoknál a közösség-jellegü általános privát és nyilvános csoportokat elemeztük, amelyek aktív besorolásúak (az elmúlt egy hónap során tapasztalt aktivitás pl. új bejegyzéssel). A célunk az volt, hogy a termékeket vagy szolgáltatásokat népszerúsítő csoportokat kizárjuk a kutatásból. Jelen cikkben a 3000 főnél nagyobb taglétszámmal rendelkező csoportokat szerepeltetjük (2. táblázat).

\section{TÁBLÁZAT}

TABLE 2

Az egészséges táplálkozással kapcsolatos Facebook-csoportok vizsgálata (Examination of Facebook Groups on Healthy Nutrition)

\begin{tabular}{|c|c|c|c|c|c|c|c|}
\hline \multirow[t]{2}{*}{$\begin{array}{l}\text { Facebook-csoportok } \\
\text { (Facebook groups) }\end{array}$} & \multirow[t]{2}{*}{$\begin{array}{l}\text { Típus } \\
\text { (Type) }\end{array}$} & \multirow{2}{*}{ 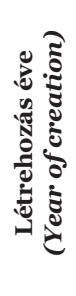 } & \multicolumn{2}{|c|}{$\begin{array}{c}\text { Csoporttagok, } \\
\text { fö } \\
\text { (Group } \\
\text { members, } \\
\text { capita) }\end{array}$} & \multirow[t]{2}{*}{ 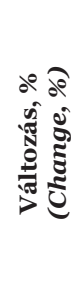 } & \multirow{2}{*}{ 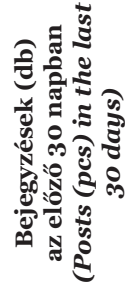 } & \multirow{2}{*}{ 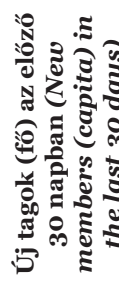 } \\
\hline & & & 2018 & 2019 & & & \\
\hline $\begin{array}{l}\text { „Reg-Enor kérdések és válaszok, tapaszta- } \\
\text { latok, információk, segítség” }\end{array}$ & $\begin{array}{l}\text { nyilvános } \\
\text { (public) }\end{array}$ & 2017 & nv & 9652 & nv & 18 & 618 \\
\hline „Bulvár, Életmód, Egészség” & $\begin{array}{l}\text { nyilvános } \\
\text { (public) }\end{array}$ & 2015 & nv & 8825 & nv & 88 & 1 \\
\hline $\begin{array}{l}\text { „Testszerviz (Fogyj másként, legyél egész- } \\
\text { séges és fitt) Neked is SIKERÜL!” }\end{array}$ & $\begin{array}{l}\text { nyilvános } \\
\text { (public) }\end{array}$ & 2015 & nv & 6763 & nv & 797 & 83 \\
\hline „108.hu Vegetáriánus Főzőklub” & $\begin{array}{l}\text { nyilvános } \\
\text { (public) }\end{array}$ & 2012 & nv & 5577 & nv & 52 & 203 \\
\hline „Életmód-Váltás-Receptekkel” & $\begin{array}{l}\text { nyilvános } \\
\text { (public) }\end{array}$ & 2017 & nv & 5114 & nv & 148 & 67 \\
\hline „Fogyókúrás receptek, egészséges életmód” & $\begin{array}{l}\text { privát } \\
\text { (private) }\end{array}$ & 2016 & 468 & 4476 & 856,4 & 25 & 784 \\
\hline „Egészséges táplálkozás fórum” & $\begin{array}{l}\text { privát } \\
\text { (private) }\end{array}$ & 2012 & 3600 & 4446 & 23,5 & 30 & 74 \\
\hline „Egészség határok nélkül” & $\begin{array}{l}\text { privát } \\
\text { (private) }\end{array}$ & 2017 & nv & 4274 & nv & 391 & 279 \\
\hline $\begin{array}{l}\text { „Egészséges életmód - természetes és népi } \\
\text { gyógymódok” }\end{array}$ & $\begin{array}{l}\text { nyilvános } \\
\text { (public) }\end{array}$ & 2013 & 2400 & 3989 & 66,2 & 71 & 66 \\
\hline $\begin{array}{l}\text { „EGÉSZSÉGES ÉTELEK, HASZNOS TIP- } \\
\text { PEK ÉLETMÓD VÁLTÁSHOZ” }\end{array}$ & $\begin{array}{l}\text { nyilvános } \\
\text { (public) }\end{array}$ & 2016 & 3500 & 3984 & 13,8 & 19 & 17 \\
\hline $\begin{array}{l}\text { „Házi praktikák, ötletek tippek, egészséges } \\
\text { életmód” }\end{array}$ & $\begin{array}{l}\text { nyilvános } \\
\text { (public) }\end{array}$ & 2013 & nv & 3946 & nv & 30 & 51 \\
\hline „Fogyás, Egészség, Életmód” & $\begin{array}{l}\text { privát } \\
\text { (private) }\end{array}$ & 2014 & 3000 & 3718 & 23,9 & 84 & 56 \\
\hline $\begin{array}{l}\text { „Egészséges táplálkozás, fogyókúra, test- } \\
\text { mozgás klub” }\end{array}$ & $\begin{array}{l}\text { privát } \\
\text { (private) }\end{array}$ & 2016 & 3400 & 3683 & 8,3 & 25 & 784 \\
\hline
\end{tabular}

Forrás (Source): Saját szerkesztés (Authors’own compilation)

*nv=nem vizsgált (not tested) 
A 2019. évi elemzés során számos, általunk korábban nem vizsgált csoportot találtunk. Ezek közül érdemes kiemelni a „Fogyókúrás receptek, egészséges életmód” privát csoportot, amelynél 856\%-os emelkedést tapasztaltunk az előző megfigyeléshez képest. Általánosan megállapítható, hogy a Facebook-csoportok elnevezéseinél az alkotók általában nem a rövid, tehát egy-két szóból álló és könnyebben megjegyezhető neveket preferálják, hanem olyan kifejezéseket találnak ki, amelyek számos kulcsszót tartalmaznak. Abban az esetben, ha weboldal is tartozik a csoporthoz, akkor azt valamilyen módon belefoglalják a csoportelnevezésbe. Néhány esetben azzal is megpróbál egy-egy csoport kitűnni, hogy csupa nagybetűvel ír bizonyos kifejezéseket a címben. A legnagyobb taglétszámú csoportok a nyilvános típusúak közül kerülnek ki. Ennek ellenére az elmúlt 30 napban (a kutatás időszakában) a két legtöbb új tagot jegyző csoport mindegyike privát típusú („Fogyókúrás receptek, egészséges életmód”, „Egészséges táplálkozás, fogyókúra, testmozgás klub”). Az elmúlt 30 napban végrehajtott új bejegyzések számában három csoport kiemelkedett az aktivitás terén („Testszerviz (Fogyj másként, legyél egészséges és fitt) Neked is SIKERÜL!” - 797 db bejegyzés; „Egészség határok nélkül” - 391 db bejegyzés; „Életmód-Váltás-Receptekkel” - 148 db bejegyzés). Azonban a többi csoportnál átlagosan 20-50 új bejegyzés kerül ki egy hónapos intervallumot figyelembe véve. A legkorábban létrehozott csoportok már 8 évesek, míg számos esetben 3-4 éves múködésről beszélhetünk. A tendenciák azt mutatják, hogy a létrehozás éve nem feltétlenül van párhuzamban az aktivitással, illetve az új tagok számával. A „fogyás” és az „egészséges táplálkozás” kifejezések fordulnak elő leggyakrabban a csoportok elnevezésénél.

\subsection{Egészségtudatos, „mentes” és növé- nyi alapú élelmiszer-fogyasztással kapcsolatos hashtagek elemzése az Instagramon -}

Analysis of Health-conscious, Free-from and Plant-based Food Consumption Related Hashtags on Instagram

Ebben a részben részletesen elemezzük az egészségtudatos, a „mentes” és a növényi alapú élelmiszer-fogyasztással kapcsolatos keresőkifejezésekhez elkülöníthető hashtag-csoportokat. Az ékezet nélküli és az ékezetes hashtageket külön vizsgáljuk.

A 3. táblázatban az egészségtudatos élelmiszer-fogyasztáshoz kapcsolódóan az „egészséges”, a „táplálkozás” és az „alakbarát” kifejezések kombinációiból elérhető hashtageket vesszük górcső alá.

A megfigyelés alapján megállapítható, hogy az egészségtudatos élelmiszer-fogyasztással kapcsolatos hashtagek jelentős részénél az ékezetes változatok nagyobb növekedést értek el az említésekben, mint az ékezet nélküliek. Tehát feltételezhető, hogy a felhasználók és vállalkozások egyre szívesebben használják a kifejezések ékezetes formáit. Különösen igaz az előző megállapítás az \#egészsegéséletmód, az \#egészségestáplálkozás és a \#tudatostáplálkozás hashtagekre. Bizonyos kifejezéseknél még mindig az ékezet nélküli forma említései mutattak nagyobb növekedést, pl. \#egeszsegesetelek, \#egeszsegesetel, \#alakbarat. Általánosan megállapítható, hogy a 2018. évi mérésekhez képest szinte minden vizsgált ékezetes és ékezet nélküli hashtag említése esetében jelentős növekedés tapasztalható. Azonban így is érdemes kiemelni az \#egeszsegesrecept/\# egészségesrecept kifejezést, hiszen itt mind a két formában 500\%-nál nagyobb növekedést figyeltünk meg. Az egészséges ételekkel kapcsolatos hashtagek is kimagaslóan teljesítettek a megfigyelési időszak során. Fontos megemlíteni, hogy a „táplálkozás” kifejezéshez kapcsolódó hashtagek manapság már inkább ékezetes formában jelennek meg a korábbiakhoz képest.

A 4. táblázatban az egészségtudatos élelmiszer-fogyasztáshoz kapcsolódó, az előzőek során még nem vizsgált hashtageket különítettük el. Ezekben közös, hogy az „egészség” kifejezés nem szerepel a kulcsszavakban. Számos hashtagnek nem különíthető el ékezetes változata.

A „diéta” kifejezés ékezetes formában való említésénél nagyobb mértékű változást tapasztaltunk, mint az ékezet nélküli formánál a vizsgált időszakban. Azonban hozzá kell tenni, hogy az ékezet nélküli változat jelentése számos nyelvterületen megegyezik, így ezzel is indokolható a közel 200 milliós említése. A \#mutimiteszel továbbra is népszerü hashtagnek minősül. A „táplálékkiegészítő” kifejezés ékezetes 
Az egészségtudatos élelmiszer-fogyasztással kapcsolatos hashtagek vizsgálata (Analysis of Health-conscious Food Consumption Related Hashtags)

\begin{tabular}{|c|c|c|c|c|c|c|c|}
\hline \multirow[t]{2}{*}{$\begin{array}{c}\text { Ékezet nélküli hashtag } \\
\text { (Hashtag without } \\
\text { accents) }\end{array}$} & \multicolumn{2}{|c|}{$\begin{array}{c}\text { Hashtag } \\
\text { említések, } \\
\text { db (Hashtag } \\
\text { mentions, pcs) }\end{array}$} & \multirow{2}{*}{ 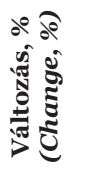 } & \multirow[t]{2}{*}{$\begin{array}{c}\text { Ékezetes hashtag } \\
\text { (Hashtag with } \\
\text { accents) }\end{array}$} & \multicolumn{2}{|c|}{$\begin{array}{c}\text { Hashtag } \\
\text { említések, } \\
\text { db (Hashtag } \\
\text { mentions, pcs) }\end{array}$} & \multirow{2}{*}{ 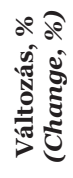 } \\
\hline & 2018 & 2019 & & & 2018 & 2019 & \\
\hline \#egeszsegeseletmod & 50038 & 99246 & 98,3 & \#egészsegéséletmód & 8109 & 49400 & 509,2 \\
\hline \# egeszsegestaplalkozas & 11892 & 31398 & 164,0 & \#egészségestáplálkozás & 4348 & 18820 & 332,8 \\
\hline \#tudatostaplalkozas & 2556 & 6294 & 146,2 & \#tudatostáplálkozás & 3166 & 21172 & 568,7 \\
\hline $\begin{array}{l}\text { \# egeszsegestaplalkozastuda- } \\
\text { tostestedzes }\end{array}$ & 912 & 1939 & 112,6 & $\begin{array}{l}\text { \# egészségestáplálkozástu- } \\
\text { datostestedzés }\end{array}$ & 0 & 8 & 0,0 \\
\hline \# egeszsegesetelek & 332 & 1802 & 442,8 & \# egészségesételek & 85 & 424 & 398,8 \\
\hline \# egeszsegesrecept & 167 & 1091 & 553,3 & \#egészségesrecept & 15 & 116 & 673,3 \\
\hline \# egeszsegesetel & 164 & 786 & 379,3 & \#egészségesétel & 1470 & 2694 & 83,3 \\
\hline \# egeszsegesetkezes & 285 & 466 & 63,5 & \#egészségesétkezés & 351 & 824 & 134,8 \\
\hline \#egeszsegeskaja & 330 & 399 & 20,9 & \#egészségeskaja & 200 & 385 & 92,5 \\
\hline $\begin{array}{l}\text { \# egeszsegestaplalkozastuda- } \\
\text { toseletvitel }\end{array}$ & 300 & 317 & 5,7 & $\begin{array}{l}\text { \# egészsegestáplálkozástu- } \\
\text { datoséletvitel }\end{array}$ & - & - & 0,0 \\
\hline \#alakbarat & 42 & 241 & 473,8 & \#alakbarát & 524 & 1358 & 159,2 \\
\hline \#alakbaratrecept & $\mathrm{o}$ & 1 & 0,0 & \#alakbarátrecept & 191 & 139 & $-27,2$ \\
\hline
\end{tabular}

Forrás (Source): Saját szerkesztés (Authors'own compilation)

4. TÁBLÁzAT

Az egészségtudatos élelmiszer-fogyasztással kapcsolatos egyéb hashtagek vizsgálata (Analysis of Other Health-conscious Food Consumption Related Hashtags)

\begin{tabular}{|c|c|c|c|c|c|c|c|}
\hline \multirow[t]{2}{*}{$\begin{array}{c}\text { Ékezet nélküli } \\
\text { hashtag (Hashtag } \\
\text { without accents) }\end{array}$} & \multicolumn{2}{|c|}{$\begin{array}{c}\text { Hashtag említések, } \\
\text { db (Hashtag } \\
\text { mentions, pcs) }\end{array}$} & \multirow{2}{*}{ 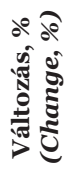 } & \multirow[t]{2}{*}{$\begin{array}{c}\text { Ékezetes hashtag } \\
\text { (Hashtag with } \\
\text { accents) }\end{array}$} & \multicolumn{2}{|c|}{$\begin{array}{c}\text { Hashtag } \\
\text { említések, } \\
\text { db (Hashtag } \\
\text { mentions, pcs) }\end{array}$} & \multirow{2}{*}{ 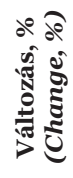 } \\
\hline & 2018 & 2019 & & & 2018 & 2019 & \\
\hline \#dieta* & 12882367 & 19265497 & 49,5 & \#diéta & 17152 & 34579 & 101,6 \\
\hline \#mutimiteszel & 1095826 & 1380340 & 26,0 & - & $\mathrm{O}$ & o & - \\
\hline \#dietas* & 389396 & 980727 & 151,9 & - & o & o & 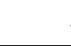 \\
\hline \#mutimiteszel_fitt & 295376 & 407688 & 38,0 & - & o & o & - \\
\hline \#dietafit & 119344 & 301516 & 152,6 & - & $\mathrm{o}$ & o & - \\
\hline \#dietafitness & 51716 & 156905 & 203,4 & - & $\mathrm{O}$ & o & - \\
\hline \#mutimiteszelfitt & 6945 & 13484 & 94,2 & - & $\mathrm{O}$ & o & - \\
\hline \#taplalekkiegeszito & 5879 & 8726 & 48,4 & \#táplálékkiegészítő & 448 & 1361 & 203,8 \\
\hline \#mutimiteszel_fit & 5501 & 6335 & 15,2 & - & $\mathrm{o}$ & $\mathrm{o}$ & - \\
\hline \# etrendkiegeszito & 254 & 763 & 200,4 & \#étrendkiegészítő & 444 & 1434 & 223,0 \\
\hline \#reformelelmiszer & 299 & 740 & 147,5 & \#reformélelmiszer & 24 & 49 & 104,2 \\
\hline \#bioelelmiszer & 8 & 18 & 125,0 & \#bioélelmiszer & 4 & 35 & 775,0 \\
\hline
\end{tabular}

Forrás (Source): Saját szerkesztés (Authors'own compilation)

*Idegen nyelven is értelmezhetők, így nem tudtuk pontosan elkülöníteni a magyar találatokat. (They can also be interpreted in a foreign language, so we couldn't accurately differentiate the Hungarian results.) 
formátuma négyszer nagyobb növekedést ért el egy év alatt, mint az ékezet nélküli változat. Az „étrendkiegészítő” kifejezésnél viszont az ékezetes és ékezet nélküli formátumnál egyaránt 200\%-nál nagyobb növekedést tapasztaltunk az említési arányban. Érdekes, hogy utóbbinál az ékezet nélküli változat is elérte ezt a magas növekedést, szemben a „táplálékkiegészítő” ki- fejezéssel. Érdemes kiemelni a „bioélelmiszer” kifejezést, amelynek ékezetes formátumánál több mint 700\%-os a növekedés, igaz, egyelőre kifejezetten alacsony az említésszám.

Az 5. táblázatban a „mentes” élelmiszer-fogyasztáshoz említhető hashtageket térképezzük fel. Számos kifejezésnek kizárólag az ékezet nélküli változatára tudtunk rákeresni.

5. TÁBLÁZAT

A „mentes” élelmiszer-fogyasztással kapcsolatos hashtagek vizsgálata

TABLE 5 (Analysis of Free-from Food Consumption Related Hashtags)

\begin{tabular}{|c|c|c|c|c|c|c|c|}
\hline \multirow[t]{2}{*}{$\begin{array}{c}\text { Ékezet nélküli hashtag } \\
\text { (Hashtag without } \\
\text { accents) }\end{array}$} & \multicolumn{2}{|c|}{$\begin{array}{c}\text { Hashtag } \\
\text { említések, } \\
\text { db (Hashtag } \\
\text { mentions, pcs) }\end{array}$} & \multirow{2}{*}{ 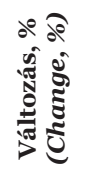 } & \multirow[t]{2}{*}{$\begin{array}{c}\text { Ékezetes hashtag } \\
\text { (Hashtag with } \\
\text { accents) }\end{array}$} & \multicolumn{2}{|c|}{$\begin{array}{c}\text { Hashtag } \\
\text { említések, } \\
\text { db (Hashtag } \\
\text { mentions, pcs) }\end{array}$} & \multirow{2}{*}{ 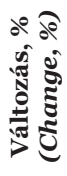 } \\
\hline & 2018 & 2019 & & & 2018 & 2019 & \\
\hline \# freefrom ${ }^{*}$ & nv & 468560 & 0,0 & - & o & $\mathrm{O}$ & - \\
\hline \#glutenmentes & 41392 & 73725 & 78,1 & \#gluténmentes & 22345 & 47482 & 112,5 \\
\hline \#mutimiteszel_mentes & 41782 & 71677 & 71,5 & - & O & $\mathrm{O}$ & - \\
\hline \#cukormentes & 34499 & 63763 & 84,8 & - & $\mathrm{O}$ & $\mathrm{O}$ & - \\
\hline \#tejmentes & 17909 & 37839 & 111,3 & - & o & o & - \\
\hline \#mindenmentes & 15776 & 31057 & 96,9 & - & 0 & $\mathrm{O}$ & - \\
\hline \#laktozmentes & 9718 & 16940 & 74,3 & \#laktózmentes & 6500 & 13789 & 112,1 \\
\hline \#tojasmentes & 3467 & 6828 & 96,9 & \#tojásmentes & 3115 & 9763 & 213,4 \\
\hline \#mutimiteszelmentes & 1011 & 2772 & 174,2 & - & $\mathrm{O}$ & $\mathrm{O}$ & - \\
\hline \#glutenmentesovezet & 759 & 1621 & 113,6 & \#gluténmentesövezet & 45 & 134 & 197,8 \\
\hline \#husmentes & 474 & 1266 & 167,1 & \#húsmentes & 1034 & 3014 & 191,5 \\
\hline \#glutenmenteselet & 490 & 1236 & 152,2 & \#gluténmentesélet & 505 & 1052 & 108,3 \\
\hline \#glutenmentesvegan & 40 & 465 & 1062,5 & \#gluténmentesvegán & 799 & 3326 & 316,3 \\
\hline \#tejmentesen & 132 & 362 & 174,2 & - & $\mathrm{O}$ & $\mathrm{O}$ & - \\
\hline \#glutenmenteselvezet & 264 & 349 & 32,2 & \#glutenmentesélvezet & 109 & 139 & 27,5 \\
\hline \#cukormentesedesseg & 75 & 87 & 16,0 & \#cukormentesédesség & 1257 & 2175 & 73,0 \\
\hline \#mindenmentesfinomsag & 8 & 8 & 0,0 & \#mindenmentesfinomság & 493 & 1015 & 105,9 \\
\hline \#mindenmenteselet & 6 & 7 & 16,7 & \#mindenmentesélet & 131 & 265 & 102,3 \\
\hline \#menteselelmiszer & 1 & 1 & 0,0 & \#mentesélelmiszer & $\mathrm{O}$ & $\mathrm{o}$ & - \\
\hline \#freefromelelmiszer & o & o & - & \#freefromélelmiszer & o & o & - \\
\hline
\end{tabular}

Forrás (Source): Saját szerkesztés (Authors'own compilation)

*Idegen nyelven is értelmezhetők, így nem tudtuk pontosan elkülöníteni a magyar találatokat. (They can also be interpreted in a foreign language, so we couldn't accurately differentiate the Hungarian results.)

A megfigyelések alapján megállapítható, hogy a nagyobb említésszámmal rendelkező „mentes” típusú táplálkozási formák szinte mindegyikénél (\#gluténmentes, \#laktózmentes, \#tojásmentes, \#húsmentes) az ékezetes változatú említésszám növekedett nagyobb mértékben az egy évvel korábbi állapothoz képest. Nagyobb mértékű növekedés tapasztalható a \#húsmentes és \#tojásmentes hashtageknél, mint a \#gluténmentes és \#laktózmentes kifejezéseknél. Azonban az említésszámok között még mindig nagy különbség azonosít- 
ható az utóbbiak javára. Érdemes kiemelni a „gluténmentesvegán” kifejezéshez kapcsolódó ékezetes és ékezet nélküli említések különösen nagy mértékű emelkedését, amely már viszonylag magas említésszámokban is megmutatkozik. Továbbá a „mindenmentes” kifejezéshez kapcsolódó hashtagek is láthatóan egyre népszerúbbek azok említése terén.
A 6. táblázatban a növényi alapú élelmiszer-fogyasztással kapcsolatos hashtagek említéseit foglaltuk össze. A megfigyelésnél törekedtünk rá, hogy a potenciálisan lehetséges összes kifejezés említését górcső alá vonjuk. Számos esetben minimálisan vagy egyáltalán nem találtunk mérhető említésszámot.

\section{TÁBLÁZAT}

A növényi alapú élelmiszer-fogyasztással kapcsolatos hashtagek vizsgálata

TABLE 6 (Analysis of Plant-based Food Consumption Related Hashtags)

\begin{tabular}{|c|c|c|c|c|c|c|c|}
\hline \multirow[t]{2}{*}{$\begin{array}{c}\text { Ékezet nélküli } \\
\text { hashtag (Hashtag } \\
\text { without accents) }\end{array}$} & \multicolumn{2}{|c|}{$\begin{array}{c}\text { Hashtag említések, } \\
\text { db (Hashtag } \\
\text { mentions, pcs) }\end{array}$} & \multirow{2}{*}{ 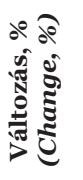 } & \multirow[t]{2}{*}{$\begin{array}{c}\text { Ékezetes hashtag } \\
\text { (Hashtag with } \\
\text { accents) }\end{array}$} & \multicolumn{2}{|c|}{$\begin{array}{c}\text { Hashtag } \\
\text { említések, } \\
\text { db (Hashtag } \\
\text { mentions, pcs) }\end{array}$} & \multirow{2}{*}{ 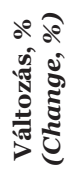 } \\
\hline & 2018 & 2019 & & & 2018 & 2019 & \\
\hline \#vegan* & 66993032 & 87396910 & 30,5 & \#vegán & 9771 & - & - \\
\hline \#paleo* & 13100693 & 14554343 & 11,1 & - & $\mathrm{O}$ & $\mathrm{O}$ & - \\
\hline \#dietapaleo* & 212942 & 424075 & 99,2 & - & $\mathrm{O}$ & $\mathrm{O}$ & - \\
\hline \#paleodieta* & 38787 & 53090 & 36,9 & paleodiéta & $\mathrm{O}$ & 155 & $\mathrm{O}, \mathrm{O}$ \\
\hline \#mutimiteszel_vegan & 17968 & 42636 & 137,3 & - & $\mathrm{O}$ & $\mathrm{O}$ & - \\
\hline \#mutimiteszel_vega & 1881 & 2737 & 45,5 & - & $\mathrm{O}$ & $\mathrm{O}$ & - \\
\hline \#vegetarianus & 945 & 1579 & 67,1 & \#vegetáriánus & 1768 & 3490 & 97,4 \\
\hline \#mutimiteszel_paleo & 825 & 1213 & 47,0 & - & $\mathrm{O}$ & $\mathrm{O}$ & - \\
\hline \#ovovegetarianus & $\mathrm{O}$ & $\mathrm{O}$ & - & \#ovovegetáriánus & $\mathrm{O}$ & $\mathrm{O}$ & - \\
\hline \#ovolaktovegetarianus & $\mathrm{O}$ & $\mathrm{O}$ & - & \#ovolaktovegetáriánus & $\mathrm{O}$ & 3 & - \\
\hline \#szemivegetarianus & o & o & - & \#szemivegetáriánus & 4 & 5 & 25,0 \\
\hline $\begin{array}{l}\text { \#novenyialaputaplal- } \\
\text { kozas }\end{array}$ & $\mathrm{O}$ & 1 & - & \#növényialapútáplálkozás & 1 & 6 & 500,0 \\
\hline \#novenyialapuelelmiszer & $\mathrm{O}$ & $\mathrm{O}$ & - & \#növényialapúélelmiszer & $\mathrm{O}$ & $\mathrm{O}$ & - \\
\hline
\end{tabular}

Forrás (Source): Saját szerkesztés (Authors'own compilation)

*Idegen nyelven is értelmezhetők, így nem tudtuk pontosan elkülöníteni a magyar találatokat. (They can also be interpreted in a foreign language, so we couldn't accurately differentiate the Hungarian results.)

A növényi alapú élelmiszer-fogyasztással kapcsolatos keresőkifejezések esetében, az ékezetes változatok sok esetben nem értelmezhetők, mert az egyes szavaknak nincsenek ékezetes betűik. Azonban érdemes kiemelni a „vegetáriánus” kifejezést, hiszen ennek ékezetes formátuma nagyobb növekedést ért el a vizsgált időszak során, mint az ékezet nélküli válto- zat. A „mutimiteszel” valamilyen növényi alapú táplálkozásra utaló kifejezéssel társítva jelen témakörnél is viszonylag magas említésszámot és növekedést ért el. A több nyelven is értelmezheto „vegan” és „paleo”, illetve ezekhez társított „dieta” kifejezések különösen magas említésszám mellett, nagymértékű növekedést is mutattak az elmúlt egy év során. 
4.3. Youtube influenszerek rendszerezése az „egészséges” élelmiszer és táplálkozás témában - Organizing Youtube Influencers on the Topic of „Healthy” Food and Nutrition

Ebben a részben a vizsgálataink alapját a Youtube közösségi videómegosztó oldal képezte. Célunk olyan magyar influenszerek és általános Youtube-csatornák feltérképezése volt, amelyek az egészségesnek vélt élelmiszerek és táplálkozás témakörében múködnek. A keresések során „beauty, életmód”, „fitnesz, életmód”, „gasztro”, „,egészséges táplálkozás, életmód” és „növényi alapú táplálkozás, vegán” keresőkifejezéseket vizsgáltuk meg (7a. és 7b. táblázat). A keresőkifejezéseket a Youtube kategorizálása alapján határoztuk meg. Az elemzéskor figyelembe vettük a Youtube-csatornák indulásának évét, a feliratkozók számát és ennek az elmúlt egy évre visszavezethető növekedési mértékét. Továbbá megfigyeltük a feltöltött videók számát és ennek is az egy évvel ezelőtti állapothoz képesti százalékos változását. A keresések során törekedtünk arra, hogy aktívnak tekinthető (az elmúlt egy évben megfigyelt aktivitás) Youtube-csatornákat vonjunk be, amelyeken legalább 1000 feliratkozó megtalálható.

7a. TÁBLÁZAT

TABLE $7 \boldsymbol{a}$

Youtube influenszerek rendszerezése az „egészséges” élelmiszer és táplálkozás témában (Organizing Youtube Influencers on the Topic of, Healthy” Food and Nutrition)

\begin{tabular}{|c|c|c|c|c|c|c|c|}
\hline \multirow[t]{2}{*}{$\begin{array}{c}\text { Influenszerek } \\
\text { (Influencers) }\end{array}$} & \multirow{2}{*}{ 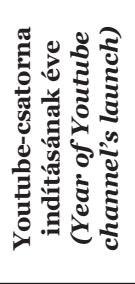 } & \multicolumn{2}{|c|}{$\begin{array}{c}\text { Feliratkozók, fő } \\
\text { (Subscribers, } \\
\text { capita) }\end{array}$} & \multirow{2}{*}{ 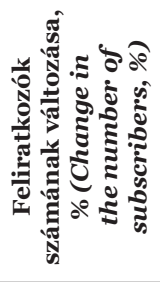 } & \multicolumn{2}{|c|}{$\begin{array}{c}\text { Feltöltött } \\
\text { videók, db } \\
\text { (Uploaded } \\
\text { videos, pcs) }\end{array}$} & \multirow{2}{*}{ 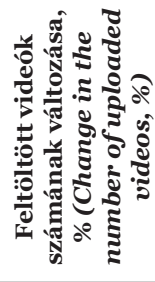 } \\
\hline & & 2018 & 2019 & & 2018 & 2019 & \\
\hline \multicolumn{8}{|c|}{ Beauty, életmód (Beauty, lifestyle) } \\
\hline „Viszkok Fruzsi” & 2011 & 338581 & 386000 & 14,0 & 482 & 597 & 23,9 \\
\hline „FollowAnna” & 2011 & 247955 & 251000 & 1,2 & 301 & 339 & 12,6 \\
\hline „AvianaRahl” & 2011 & $\mathrm{nv}^{*}$ & 167000 & nv & $\mathrm{nv}$ & 503 & nv \\
\hline „Lina és Panni” & 2013 & 118466 & 134000 & 13,1 & 357 & 450 & 26,1 \\
\hline „Plaura” & 2011 & $\mathrm{nv}$ & 130000 & nv & nv & 275 & nv \\
\hline „Alexy Vivien” & 2013 & $\mathrm{nv}$ & 94000 & nv & nv & 245 & nv \\
\hline „Soulshine by Andi” & 2016 & 62960 & 74800 & 18,8 & 189 & 225 & 19,0 \\
\hline „Dorina Marbelouss” & 2012 & 67838 & 70600 & 4,1 & 211 & 222 & 5,2 \\
\hline „Tucsi Channel” & 2011 & $\mathrm{nv}$ & 63500 & nv & nv & 147 & nv \\
\hline „csivettka” & 2011 & $\mathrm{nv}$ & 42700 & nv & nv & 202 & nv \\
\hline „Sydney van den Bosch” & 2012 & $\mathrm{nv}$ & 26400 & nv & nv & 80 & nv \\
\hline „Glamify HU” & 2015 & nv & 23300 & nv & $\mathrm{nv}$ & 201 & nv \\
\hline „Takacs_Norie” & 2015 & $\mathrm{nv}$ & 22200 & $\mathrm{nv}$ & nv & 419 & nv \\
\hline „Szakács Lilla” & 2016 & 11856 & 18500 & 56,0 & 67 & 121 & 80,6 \\
\hline „Tatár Csilla” & 2017 & $\mathrm{nv}$ & 18300 & $\mathrm{nv}$ & nv & 86 & nv \\
\hline „Vászonzsákoslány” & 2019 & $\mathrm{nv}$ & 17400 & $\mathrm{nv}$ & $\mathrm{nv}$ & 16 & nv \\
\hline „Viszkok Fruzsi” & 2011 & 338581 & 386000 & 14,0 & 482 & 597 & 23,9 \\
\hline „FollowAnna” & 2011 & 247955 & 251000 & 1,2 & 301 & 339 & 12,6 \\
\hline „AvianaRahl” & 2011 & $\mathrm{nv}$ & 167000 & nv & nv & 503 & nv \\
\hline
\end{tabular}

Forrás (Source): Saját szerkesztés (Authors'own compilation)

*nv=nem vizsgált (not tested); **két éve inaktívak (inactive for two years) 
Youtube influenszerek rendszerezése az „egészséges” élelmiszer és táplálkozás témában (Organizing Youtube Influencers on the Topic of „Healthy” Food and Nutrition)

\begin{tabular}{|c|c|c|c|c|c|c|c|}
\hline \multirow[t]{2}{*}{$\begin{array}{l}\text { Influenszerek } \\
\text { (Influencers) }\end{array}$} & \multirow{2}{*}{ 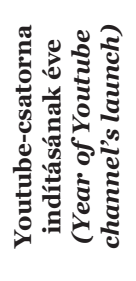 } & \multicolumn{2}{|c|}{$\begin{array}{c}\text { Feliratkozók, fó } \\
\text { (Subscribers, } \\
\text { capita) }\end{array}$} & \multirow{2}{*}{ 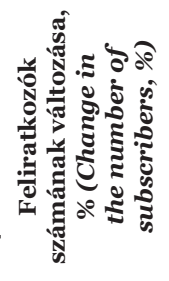 } & \multicolumn{2}{|c|}{$\begin{array}{c}\text { Feltöltött } \\
\text { videók, db } \\
\text { (Uploaded } \\
\text { videos, pcs) }\end{array}$} & \multirow{2}{*}{ 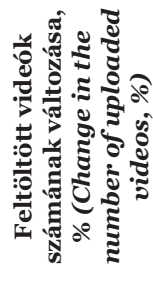 } \\
\hline & & 2018 & 2019 & & 2018 & 2019 & \\
\hline \multicolumn{8}{|c|}{ Fitnesz, életmód (Fitness, lifestyle) } \\
\hline „Janos Orosz Fitness”** & 2012 & 36375 & 39800 & 9,4 & 74 & 74 & 0,0 \\
\hline „Eniko Pentek” & 2011 & $\mathrm{nv}$ & 25300 & nv & nv & 227 & nv \\
\hline „Gökler Kriszti” & 2015 & 20417 & 25200 & 23,4 & 191 & 243 & 27,2 \\
\hline „Béres Alexandra” & 2015 & 13590 & 18100 & 33,2 & 110 & 148 & 34,5 \\
\hline „Tündi Gazdag” & 2013 & 12952 & 16900 & 30,5 & 110 & 144 & 30,9 \\
\hline „Katus Attila” & 2014 & 1658 & 3006 & 81,3 & 106 & 110 & 3,8 \\
\hline \multicolumn{8}{|c|}{ Gasztro (Gastro) } \\
\hline $\begin{array}{l}\text { „Inspirációk Magazin - Csorba } \\
\text { Anita” }\end{array}$ & 2015 & $\mathrm{nv}$ & 82500 & nv & nv & 181 & nv \\
\hline „SütikBirodalma-Szandi” & 2011 & 31734 & 39900 & 25,7 & 123 & 142 & 15,4 \\
\hline $\begin{array}{l}\text { „Buday Péter, a Zsebsza- } \\
\text { kács”*** }\end{array}$ & 2014 & 8362 & 12000 & 43,5 & 160 & 160 & 0,0 \\
\hline \multicolumn{8}{|c|}{ Egészséges táplálkozás, életmód (Healthy nutrition, lifestyle) } \\
\hline „Eszter Gottschall” & 2015 & 28118 & 40300 & 43,3 & 151 & 183 & 21,2 \\
\hline $\begin{array}{l}\text { „Éhezésmentes Karcsúság } \\
\text { Szafival” }\end{array}$ & 2013 & 11624 & 15700 & 35,1 & 58 & 74 & 27,6 \\
\hline „Martina Klein” & 2017 & 7801 & 15400 & 97,4 & 64 & 128 & 100,0 \\
\hline „Zsebibogyó” & 2017 & nv & 13100 & $\mathrm{nv}$ & nv & 147 & nv \\
\hline „KingaBella” & 2016 & $\mathrm{nv}$ & $475^{\circ}$ & nv & nv & 75 & nv \\
\hline „Eszel, edzel, jól leszel!” & 2017 & $\mathrm{nv}$ & 4660 & $\mathrm{nv}$ & $\mathrm{nv}$ & 101 & nv \\
\hline „Csenge Kiszely” & 2012 & 1534 & 2770 & 80,6 & 59 & 39 & $-33,9$ \\
\hline „Judit Hosnyánszki” & 2013 & 2033 & 2660 & 30,8 & 6 & 17 & 183,3 \\
\hline „Barbara Life” & 2013 & 1054 & 1300 & 23,3 & 327 & 386 & 18,0 \\
\hline \multicolumn{8}{|c|}{ Növényi alapú táplálkozás, vegán (Plant-based nutrition, vegan) } \\
\hline „Székely Vegán” & 2010 & 20887 & 23600 & 13,0 & 2399 & 2623 & 9,34 \\
\hline $\begin{array}{l}\text { „NoraSpiration - Boldogság } \\
\text { növényi alapokon” }\end{array}$ & 2015 & 6522 & 8650 & 32,6 & 113 & 133 & 17,70 \\
\hline „Click Vegan” & 2016 & $\mathrm{nv}$ & 4360 & nv & nv & 23 & nv \\
\hline „Vegan_Kriszti” & 2013 & 1343 & 1560 & 16,2 & 86 & 96 & 11,63 \\
\hline
\end{tabular}

Forrás (Source): Saját szerkesztés (Authors' own compilation)

*nv=nem vizsgált (not tested); **két éve inaktívak (inactive for two years) 
A „beauty, életmód” kategóriában találtuk a legtöbb influenszert a vizsgált kategóriák közül. Azonban feltétlenül ki kell hangsúlyozni, hogy a kategória képviselői csak alkalmanként foglalkoznak az egészséges élelmiszer-fogyasztással, amelyet többnyire az egészséges életmóddal kapcsolatos videóik tartalmazzák. A 2018. évi megfigyeléshez képest számos új influenszert találtunk. A korábbiakban is vizsgáltak közül „Szakács Lillát” érdemes kiemelni, aki a feliratkozók számának változásában és a videós feltöltések gyakoriságában egyaránt kiemelkedőnek bizonyult. Általános tendenciaként értelmezhető, hogy az influenszerek többsége már közel 10 éve végzi a tevékenységét (2011 óta). Kevés olyan influenszer említhető (pl. „Tatár Csilla”, „Vászonzsákoslány”), akik néhány év alatt tudtak jelentősebb sikert elérni ebben a kategóriában.

A „fitnesz, életmód” témakörben „János Orosz Fitness” csatornája továbbra is magasan a legnépszerübb. Habár a bejegyzések alapján ebben az esetben 2 éve inaktivitás tapasztalható, így is 10\%-os növekedés tapasztalható az egy év alatt újonnan csatlakozó felhasználók esetében. A kategória legnépszerúbb képviselőinél („Gökler Kriszti”, „Béres Alexandra”, „Tündi Gazdag”) egyaránt kb. 30\%-os növekedés állapítható meg az új követők és az új bejegyzések esetében. Katus Attila alacsonyabb követőtáborral rendelkezik a korábban említett szereplőkhöz képest, azonban nagyobb növekedést (81\%) tudott elérni a feliratkozók esetében az elmúlt egy évet figyelembe véve. A megfigyelt influenszerek mindegyike legalább 4-5 éve végzi a tevékenységét.

"Gasztro" témakörben három olyan infulencert találtunk, akik többnyire az egészséges táplálkozással kapcsolatban posztolnak videókat. „Buday Péter, a Zsebszakács” úgy tudott elérni egy év alatt 43,5\%-os növekedést a feliratkozók terén, hogy 2 éve inaktív a csatornája. „SütikBirodalma-Szandi” kifejezetten magas feliratkozószámmal rendelkezik, és növekedő tendenciát mutat a feliratkozók és a feltöltött videók számában egyaránt. „Inspirációk Magazin - Csorba Anita” a jelenleg vizsgált csatornán kívül másikkal is rendelkezik, azonban ez az a Youtube-fiók, amelyen többnyire az egészséges táplálkozással kapcsolatos meglátásait osztja meg a követőivel, akik különösen nagy számban vannak már jelen.

Az „életmód, egészséges táplálkozás” kategória számos influenszert foglal magába, akiknek a többsége 4-5 éve indította a csatornáját. „Eszter Gottschall” magasan a legtöbb feliratkozóval rendelkezik (4030o feliratkozó). „Martina Klein” 2017-ben indította a csatornáját, amellyel kiugró növekedést tudott elérni az elmúlt egy év során a feliratkozók $(97,4 \%)$ és a feltöltött videók számának (100\%) növekedésében. A példája is jól mutatja, hogy az adott témakörben érdemes videókat feltölteni, hiszen magas igény mutatkozik rá.

„Növényi alapú táplálkozás és vegán” kategóriában viszonylag kevés véleményvezér található. Közülük a legnégyszerúbbnek egyértelmüen „Székely Vegán” bizonyult (23600 feliratkozó), aki már 10 éve sikeresen múködteti a csatornáját. Feltétlenül ki kell emelni a feltörekvő influenszerek közül „NoraSpiration - Boldogság növényi alapokon” csatornáját, hiszen a 2018. évi megfigyeléshez képest 2019re 32,6\%-os növekedést ért el a feliratkozók számában és 17,7\%-os növekedést a feltöltött videók esetében. Megállapítható, hogy növényi alapú táplálkozás egyre nagyobb hazai népszerüsége kevésbé mutatkozik meg az egyes influenszerek tevékenységében. Az elmúlt években nem volt olyan magyar csatorna, amely népszerűsége kiemelkedő lett volna.

Az elemzés során külön figyelmet fordítottunk azokra a Youtube-csatornákra, amelyek nem köthetők egyértelmüen valamely influenszerhez (8. táblázat).

A 2018. évi elemzéshez képest számos új oldalt találtunk a 2019-es megfigyelés során. A korábbiakban is vizsgáltak esetében érdemes kiemelni a „Nosalty” és a „Mindmegette.hu” csatornákat, hiszen kiemelkedő növekedést értek el az új feliratkozók és a feltöltött videók számában egyaránt. A „Mindmegette.hu” esetében tapasztalt közel 400\%-os feliratkozói növekedés külön említést érdemel. Továbbá a „Nosalty” töretlen népszerüsége is bizonyítható, hiszen a vizsgált oldalak közül a legrégebbinek minősül (2009. évi létrehozás). A vizsgált oldalak háttere különösen sokszínü, megtalálhatók különféle márkákkal kapcsolatos oldalak (pl. Cutler Gym Tv), hazai szervezetek csatornái (pl. Nébih), illetve egy magazinnal kapcsolatos felület (pl. Vitaflex Magazin). 
A Youtube-csatornák rendszerezése az „egészséges” élelmiszer és táplálkozás témában (Organizing Youtube Channels on the Topic of „Healthy” Food and Nutrition)

\begin{tabular}{|c|c|c|c|c|c|c|c|}
\hline \multirow[t]{2}{*}{$\begin{array}{c}\text { Youtube-csatornák } \\
\text { (Youtube Channels) }\end{array}$} & \multirow{2}{*}{ 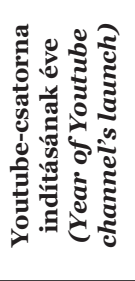 } & \multicolumn{2}{|c|}{$\begin{array}{c}\text { Feliratkozók, fó } \\
\text { (Subscribers, } \\
\text { capita) }\end{array}$} & \multirow{2}{*}{ 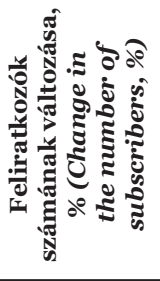 } & \multicolumn{2}{|c|}{$\begin{array}{c}\text { Feltöltött } \\
\text { videók, db } \\
\text { (Uploaded } \\
\text { videos, pcs) }\end{array}$} & \multirow{2}{*}{ 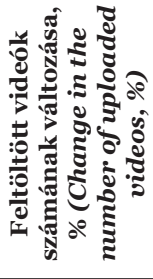 } \\
\hline & & 2018 & 2019 & & 2018 & 2019 & \\
\hline „Miele Főzőiskola” & 2010 & $\mathrm{nv}^{*}$ & 35400 & nv & nv & 661 & nv \\
\hline „NoSalty” & 2009 & 16413 & 34600 & 110,8 & 1176 & 1659 & 41,1 \\
\hline „Vitaflex magazin” & 2013 & 21600 & 23800 & 10,2 & 130 & 142 & 9,2 \\
\hline „Mindmegette.hu” & 2016 & 2974 & 14800 & 397,6 & 511 & 950 & 85,9 \\
\hline „Sportaholic” & 2016 & nv & 13700 & nv & nv & 143 & nv \\
\hline „Jóga Életmód” & 2017 & nv & 12700 & nv & nv & 97 & nv \\
\hline „Cutler Gym TV” & 2017 & nv & 11900 & nv & nv & 27 & nv \\
\hline „Nébih” & 2013 & nv & 3120 & nv & nv & 300 & nv \\
\hline „Táplálkozás-Beállítás” & 2014 & nv & 1100 & nv & nv & 29 & nv \\
\hline „TIE Videók”** & 2015 & 545 & 963 & 76,7 & 198 & 198 & 0,0 \\
\hline „Napi Fitt Konyha” & 2016 & nv & 808 & nv & nv & 41 & nv \\
\hline „Netamin” & 2012 & $\mathrm{nv}$ & 566 & nv & nv & 43 & $\mathrm{nv}$ \\
\hline $\begin{array}{l}\text { „FÉLT Funkcionális Élelmi- } \\
\text { szerlánc Terméktanács”*** }\end{array}$ & 2015 & 176 & 297 & 68,8 & 15 & 15 & 0,0 \\
\hline
\end{tabular}

Forrás (Source): Saját szerkesztés (Authors'own compilation)

*nv=nem vizsgált (not tested); **három-négy éve inaktívak (inactive for three-four years)

\section{4. ÖSSZEFOGLALÁs - SUMMARY}

Tanulmányunkban a netnográfia módszerével feltérképeztük az egészségtudatos élelmiszer-fogyasztás közösségi médiában való megjelenését. A kutatási eredmények alapján releváns információkat kaptunk a kutatási kérdéseinkre. A következőkben a fontosabb eredményeket és tendenciákat foglaljuk össze.

Az egészséges táplálkozással kapcsolatos Facebook-oldalaknál (nem üzletszerü, aktív és minimum 5000 kedvelő), azok kategóriáját alátámasztó keresőkifejezéseket figyelembe véve nem állapítható meg egyértelmű tendencia. A vizsgált témakörrel (pl. „egészséges életmód” és „tudatos táplálkozás”) kapcsolatos kifejezéseknél az esetek többségében ugyanazokat az oldalakat azonosítottuk. Tehát egy adott oldal több keresőkifejezésnél is megjelent.

A megfigyelt Facebook-csoportoknál (álta- lános/közösségi jellegü, aktív, privát és nyilvános, 3000 főnél nagyobb taglétszámú) általánosan megállapítható, hogy azok elnevezései esetében általában nem az egy-két szóból álló rövid kifejezéseket alkalmazzák a csoport létrehozói, hanem akár 4-5 kulcsszót egyszerre adnak meg. A meglévő weboldal nevét szinte minden esetben belefoglalják a csoportelnevezésbe. A megfigyelt csoportok elnevezéseinél a „fogyás” és az „egészséges táplálkozás” kifejezések fordulnak elő leggyakrabban valamilyen szövegkörnyezetben. Megállapítható, hogy a csoport létrehozásának éve nem feltétlenül vonható párhuzamba az új tagok számával és a csoport aktivitásával. Tehát a régebben létrehozott, de azóta is népszerű oldalak képesek ugyanolyan hatékonyan és aktívan múködni, mint az újabb csoportok. Érdemes a csoporttagok között is egy olyan közösséget kialakítani, akik megfelelően aktívan tudják tartani 
a csoport múködését, ezzel is prezentálva az újonnan csatlakozó tagoknak, hogy érdemes a csoport bejegyzéseit figyelniük.

Az Instagram közösségi oldalon az egészségtudatos, a „mentes” és a növényi alapú élelmiszer-fogyasztással kapcsolatos ékezetes és ékezet nélküli, magyar nyelven is értelmezhető hashtageket vontuk be a vizsgálatba. A tendenciák alapján megállapítható, hogy az egészségtudatos élelmiszer-fogyasztáshoz kapcsolódó hashtagek többségénél jelentős növekedést értek el az ékezetes változatú kifejezések a vizsgált időintervallumban. Az „egészséges recepthez” és az „egészséges ételekhez” kapcsolódó ékezetes és ékezet nélkül hashtagek egyaránt kifejezetten nagy növekedést értek el. Továbbá megállapítottuk, hogy a „táplálkozás” kifejezést tartalmazó hashtagek jelentős része manapság már inkább az ékezetes változattal szerepel. A „mutimiteszel” hashtag önmagában és egyéb kifejezésekkel való használata népszerünek minősül. A „táplálékkiegészítő” és „étrendkiegészítő” hashtagek említésszáma is jelentősen nőtt egy év alatt, utóbbi esetben ráadásul az ékezetes és ékezet nélküli forma is népszerűnek bizonyult. Fontos még kiemelni, hogy a „mentes” típusú táplálkozási formák többségénél (pl. „gluténmentes”, „laktózmentes") az ékezetes változatú szóösszetételek említései az egy évvel korábbi vizsgálatokhoz képest kifejezetten nagy növekedést értek el. A „gluténmentesvegán” hashtag ékezetes és ékezet nélküli változata érte el a legnagyobb növekedést (316\% és 1063\%), amely jól alátámasztja napjaink trendjeit. Ezzel kapcsolatban megemlíthető még a „mindenmentes” kifejezéshez kapcsolódó hashtagek kiugró népszerüsége. A növényi alapú élelmiszer-fogyasztással kapcsolatos hashtagek jelentős része (pl. „vegan”, „paleo” és „dieta) több idegen nyelven is értelmezhető, az ékezet nélküli magas említésszámok is ezt támasztják alá. Az ilyen típusú kifejezések többségénél az ékezetes változatok nem értelmezhetők, vagy alacsony számú említést kaptak.
Végül, de nem utolsó sorban olyan magyar influenszereket vizsgáltunk, akik népszerűnek bizonyultak az egészségesnek vélt élelmiszerek és táplálkozás témakörben. A „beauty, életmód” témában találtuk a legtöbb influenszert. Azonban ennek a kategóriának a képviselői csupán részben foglalkoznak a posztjaikban az egészséges élelmiszer-fogyasztással. Érdemes kiemelni, hogy mindössze két olyan influenszert találtunk („Tatár Csilla” és „Vászonzsákoslány”), akik néhány év alatt értek el jelentősebb számú feliratkozó közönséget. Az „életmód, egészséges táplálkozás” kategória képviselői az előzőekhez hasonlóan szintén nagy számban vannak jelen és többségük 4-5 éve múködő csatornát üzemeltet. Ennél a témánál „Martina Klein” 2017-ben indított csatornája lehet példaértékü, hiszen rövid idő alatt ért el kiugró feliratkozószámot (40 300 fő). Az előzetes várakozásokkal ellentétben a „növényi alapú táplálkozás és vegán” kategóriában különösen kevés véleményvezért tudtunk azonosítani. Tehát megállapítható, hogy a manapság már hazánkban is oly népszerü influenszerek az egészséges táplálkozás és egészséges életmód témakörökben viszonylag alacsony számban képviseltetik magukat.

Összességében elmondható, hogy a közösségi médiában az egészséges életmód említése komplex módon érvényesül és kevésbé szükíthető le csupán az egészségtudatos élelmiszer-fogyasztásra.

\section{KöSZÖNETNYILVÁNÍTÁS -}

\section{ACTKNOWLEDGEMENT}

„A tudományos közlemény elkészítését az EFOP-3.6.1-16-2016-00022 számú projekt támogatta. A projekt az Európai Unió támogatásával, az Európai Szociális Alap társfinanszírozásával valósult meg." 
IRODALOMJEGYZÉK - REFERENCES

Bernát, A.: Hazai egészséggazdaság. „Marketing, public relations és reklám az egészségügyben” XV. Országos Konferencia. Budapest, 2012. február 1617.

Bíró, Gy.: A hazai zsiradékfogyasztás változásának közegészségügyi hatásai. Élelmezési Ipar. 2008. 65 (5) 137-141.

Dörnyei, K.: Bioélelmiszer fogyasztási szokások. Marketing \& Menedzsment. 2008. (4) 34-42.

Dörnyei, K. - Mitev, A.: Netnográfia, avagy on-line karosszék-etnográfia a marketingkutatásban. Vezetéstudomány. 2010. 41 (4) 55-68.

Eurostat: Self-perceived Health by Sex, Age and Groups of Country of Citizenship. 2018a. https://appsso.eurostat. ec.europa.eu/nui/show.do?dataset=hlth silc_24\&lang=en (Letöltés dátuma: 2019.12.08.)

Eurostat: Individuals Using the Internet for Seeking Health-Related Information. 2018b. https://ec.europa.eu/eurostat/ databrowser/view/tino0101/default/ table?lang=en (Letöltés dátuma: 2019.12.08.)

Farkas, N. D.: Az egészséges táplálkozás megítélése a hazai fogyasztók körben. Tudományos Diákköri Dolgozat. Debreceni Egyetem, Debrecen, 2019.

Fehér, A.: Az online fogyasztói magatartás vizsgálata az élelmiszeriparban. Doktori disszertáció. Debreceni Egyetem, Gazdaságtudományi Kar, Ihrig Károly Gazdálkodási- és Szervezéstudományok Doktori Iskola. 2016.

Forgács, A. - Forgács, D. - Forgács, D.: Globesity, a tömeges elhízás pszichológiája. Magyar Tudomány. 2013. 174 (7) 811-819.

Gál, T. - Soós, M. - Szakály, Z.: Egészségtudatos kapcsolatos fogyasztói insight-ok feltárása netnográfiával - esettanulmány. Vezetéstudomány. 2017. 68 (4) 4654. DOI: https://doi.org/10.14267/ VEZTUD.2017.04.07
GfK: Magyar egészségszegmensek. Egészséggazdasági Monitor. 2012.

Halmos, J. Cs. - Kis, R. - Andorkó, D.: Útravalók influencerezéshez. Médiapiac. 2018. 15 (9-10) 56-57.

Harris, D. M. - Guten, S.: Health Protective Behaviour: An Exploratory study. Journal of Health and Social Behaviour. 1979. 20 17-29. DOI: https:// doi.org/10.2307/2136475

Hootsuite Digital: Digital in 2018 in Eastern Europe. 2018. https://www.slideshare. net/wearesocial/digital-in-2018-ineastern-europe-part-1-west-86864848 (Letöltés dátuma: 2019.12.08.)

INOW Research: Generációk és online platformok Magyarországon. 2018. https://www.slideshare.net/cousteau/ inow-kozossegimedia2018q1 (Letöltés dátuma: 2019.12.08.)

IWS: Internet Users in the World, EU and Hungary. 2019. https://www. internetworldstats.com/stats 9.htm (Letöltés dátuma: 2019.12.08.)

Jánoska, R.: \#Followme. Marketing\&Media. 2018. 23 (2) 22-23.

Kéri, G.: Influencer-marketing. Már csak rajtuk keresztül lehet bármit eladni? Új intézmény megszületőben. Social Media 2018 A romló elérések hatásos ellenszerei. Piac \& Profit Konferencia. Budapest, 2018. szeptember 6.

Lalonde, M.: A New Perspective on the Health of Canadians. A Working Document. Ottawa: Government of Canada. 1974.

Majláth, R.: A youth marketing sokkal több influencerek felbérelésénél. Médiapiac. 2018. 15 (9-10) 54-55.

Máté, B.: \#Hashtag a Facebook-on is: Így múködik, és így tudod helyesen használni! 2014. https://matebalazs.hu/ hashtag-facebook.html (Letöltés dátuma: 2019.12.18.)

Mohsin, M.: 10 Social Media Statistics You Need to Know in 2019. https:// www.oberlo.com/blog/social-mediamarketing-statistics (Letöltés dátuma: 2019.03.28.) 
Moskowitz, H. - Beckley, J. - MinkusMckenna, D.: Use of Conjoint Analysis to Assess Web-Based Communications on Functional Foods. Appetite. 2004. 43 (1) 85-92. DOI: https://doi.org/10.1016/j. appet.2004.03.003

Petruska, I.: Fogyasztói magatartás. In: Marketing: Fókuszban a termék. (Szerk. Horváth, B. - Marsi, M.). Typotex kiadó, Budapest, 2017. 71-90.

Social Daily: 35 tény az Instagramról, amit tudni érdemes. 2017. https://socialdaily. com/35-teny-az-instagramrol-amit-tudnierdemes/ (Letöltés dátuma: 2019.12.18.)

Szakály, Z.: Táplálkozásmarketing. Mezőgazda Kiadó. Budapest, 2011.

Szakály, Z. - Kovács, S. - Pető, K. Huszka, P. - Kiss, M.: A Modified Model of the Willingness to Pay For Functional Foods. Appetite. 2019. 138 94-101. DOI: https://doi.org/10.1016/j. appet.2019.03.020

Szántó, Á.: Egészségpiac és egészségtudatosság - vásárlói döntést befolyásoló tényezők marketing szemléletű vizsgálata. Doktori disszertáció. Miskolci Egyetem, Gazdaságtudományi Kar, Vállalkozáselmélet és gyakorlat Doktori Iskola, Miskolc, 2008.
Székely, G. - Sipos, L. - Losó, V.: FMCG marketing. Aula Kiadó, Budapest, 2009.

Szilágyi, K.: Robban az influencerpiac. Marketing\&Media. 2018. 23 (8) 48-49.

Tari, K.: Online élelmiszervásárlási szokások és lehetôségek vizsgálata magyar és amerikai online vásárlók körében. Táplálkozásmarketing. 2018. 5 (2) 3143. DOI: https://doi.org/10.20494/ $\mathrm{TM} / 5 / 2 / 3$

Töröcsik, M.: Fogyasztói magatartás Insight, trendek, vásárlók. Akadémiai Kiadó, Budapest, 2011.

Tringer, L.: A mentális betegségek megelőzésének és ellátásának korszerú szemlélete. Orvostovábbképző Szemle. 2002. 9 (1) 12-21.

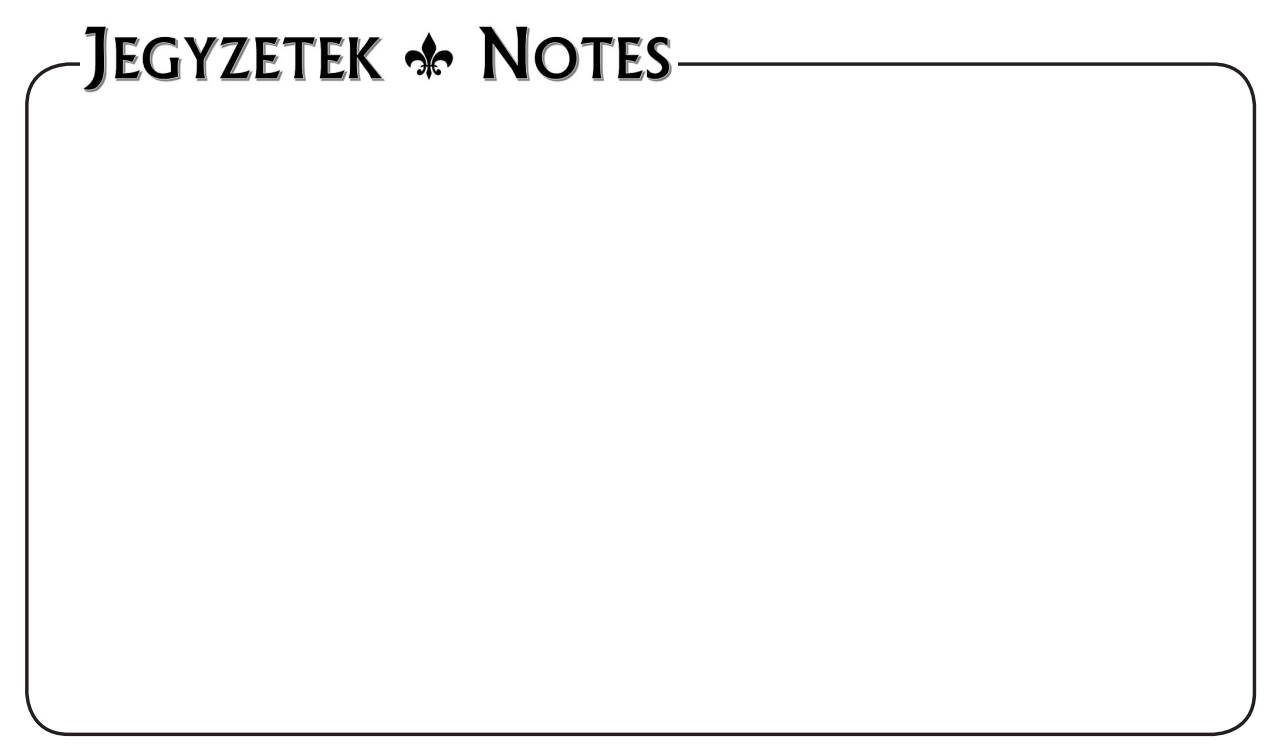

